\title{
MEKANISME GOOD CORPORATE GOVERNANCE, KUALITAS AUDIT, UKURAN PERUSAHAAN DAN KORELASINYA TERHADAP NILAI PERUSAHAAN DENGAN MANAJEMEN LABA SEBAGAI VARIABEL INTERVENING
}

\author{
Gilang Darmawang ${ }^{1)}$, \\ ${ }^{1)}$ Program Studi Magister Akuntansi \\ Fakultas Ekonomi dan Bisnis Universitas Pancasila \\ email: darmawanggilang@gmail.com \\ Suratno ${ }^{2)}$ \\ 2) Program Studi Magister Akuntansi \\ Fakultas Ekonomi dan Bisnis Universitas Pancasila \\ Muhammad Yusuf ${ }^{3)}$ \\ 3) Program Studi Magister Akuntansi \\ Fakultas Ekonomi dan Bisnis Universitas Pancasila
}

\begin{abstract}
This study aims to identify, analyze, demonstrate and test the mechanisms of good corporate governance, audit quality, the size of the company and its correlation on the value of the company with earnings management as an intervening variable in manufacturing companies and consumer goods industry sectors listed on the Indonesia Stock Exchange period 2011-2015. This study uses secondary data to see and obtain data from the Indonesia Stock Exchange. The research method in this research is by using Path Analysis with two substructures. The results show that good corporate governance partially no effect on earnings management, audit quality has influence but not significant to earnings management, the size of the company has a significant influence on earnings management, good corporate governance with significant influence on the value of the company, audit quality has an impact and significantly to the value of the company, company size has no significant effect on firm value. The tests are based on a confidence level of 95\%, and an error rate of $5 \%$.
\end{abstract}

Keywords: Good Corporate Governance, Quality Audit, Company Size, Earnings Management and Corporate Values

\section{PENDAHULUAN}

Sejalan dengan perkembangan perekonomian, setiap perusahaan dituntut untuk dapat mengembangkan kualitasnya demi keberlangsungan usahanya. Manajemen perusahaan harus mampu menilai seberapa besar usahanya memberikan dampak yang positif atau dapat memberikan laba yang besar. Karena didirikannya sebuah perusahaan memiliki tujuan yang jelas. Ada beberapa hal yang mengemukakan tentang tujuan pendirian suatu perusahaan. Tujuan perusahaan yang pertama adalah untuk mencapai keuntungan maksimal atau laba yang sebesar-besarnya.
Tujuan perusahaan yang kedua adalah ingin memakmurkan pemilik perusahaan atau para pemilik saham. Sedangkan tujuan perusahaan yang ketiga adalah memaksimalkan nilai perusahaan yang tercermin pada harga sahamnya.

Perusahaan yang telah berjalan pastinya akan memperhatikan tentang nilai perusahaan. Secara teknis sendiri nilai perusahaan salah satu faktor perusahaan untuk mendapatkan dana dari eksternal dengan cara mengeluarkan saham dan obligasi yang diterbitkan di pasar modal. Tinggi rendahnya harga saham dan obligasi banyak dipengaruhi oleh kondisi emiten atau 
perusahaan yang mengeluarkan surat - surat berharga.

Dalam proses memaksimalkan nilai perusahaan akan muncul konflik kepentingan antara manajer dan pemilik perusahaan yang sering disebut dengan Agency Problem. Tidak jarang manajemen perusahaan memiliki tujuan lain yang mungkin bertentangan dengan tujuan utama perusahaan. Perbedaan kepentingan inilah yang menyebabkan timbulnyakonflik yang biasa disebut dengan Agency Conflict. Perbedaan tersebut terjadi karena manajer mengutamakan kepentingan pribadi, sebaliknya para pemegang saham tidak menyukai kepentingan pribadi dari manajer karena apa yang dilakukan manajer tersebut akan menambah biaya dari perusahaan sehingga menyebabkan penurunan keuntungan perusahaan dan dividen yang akan diterima oleh pemegang saham (Haruman, 2008).

Berikut ini adalah tabel hasil pengamatan perkembangan nilai perusahaan manufaktur sektor industri barang dan konsumsi tahun 2011-2015, hasilnya adalah sebagai berikut :

Tabel -1

\section{Perkembangan Nilai Perusahaan}

\begin{tabular}{|c|c|}
\hline Tahun & Nilai Perusahaan \\
\hline 2011 & $344,32 \%$ \\
\hline 2012 & $395,11 \%$ \\
\hline 2013 & $406,78 \%$ \\
\hline 2014 & $414,12 \%$ \\
\hline 2015 & $223,80 \%$ \\
\hline
\end{tabular}

Berdasarkan data dari tabel diatas penulis membuat grafik perkembangan nilai perusahaan manufaktur sektor industri barang dan konsumsi sebagai berikut :

\section{Gambar - 1 \\ Perkembangan Nilai Perusahaan Manufaktur Sektor Barang Industri dan Konsumsi Periode 2011 - 2015}

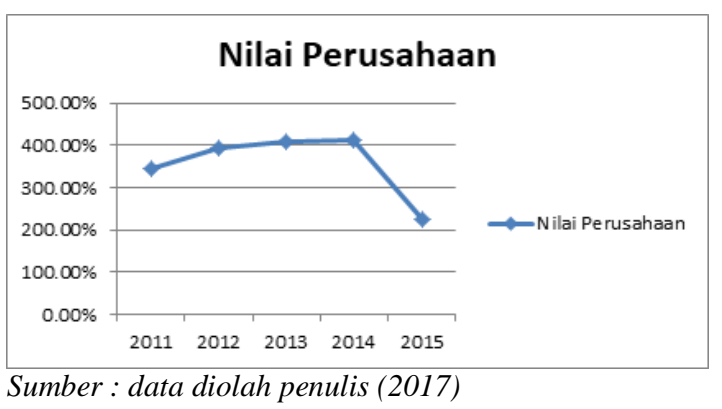

Sumber : data diolah penulis (2017)

Gambar-1 memperlihatkan perkembangan nilai perusahaan manufaktur sektor industri barang dan konsumsi yang terdaftar di BEI periode 2011-2015. Dari grafik tersebut terlihat perkembangan nilai perusahaan yang di analisa menggunakan tobin's q. Pada tahun 2011 hingga 2015 perkembangan nilai perusahaan manufaktur sektor industri barang dan konsumsi cenderung naik, dengan nilai secara berturut - turut adalah 344,32\%, 395,11\%, $406,78 \%$ dan $414,12 \%$. Namun pada tahun 2015 perkembangan nilai perusahaan turun drastis menjadi sebesar 223,80\%. Hal tersebut menunjukkan bahwa fenomena kondisi nilai perusahaan manufaktur sektor industri barang dan konsumsi tersebut tidak stabil. Dan sebagaimana kita ketahui bahwa nilai perusahaan inilah yang menjadi salah satu tolak ukur para investor untuk menanamkan modalnya di suatu perusahaan. Oleh sebab itu pula penelitian ini menjadi menarik untuk diteliti untuk menganalisis faktor - faktor apa saja yang dapat membuat nilai suatu perusahaan mempunyai nilai yang baik dimata investor.

\section{TINJAUAN PUSTAKA}

Tentunya terdapat banyak sekali faktor faktor yang dapat menentukan nilai perusahaan. Ukuran perusahaan dianggap mampu mempengaruhi nilai perusahaan. Karena semakin besar ukuran atau skala perusahaan maka akan semakin mudah pula perusahaan memperoleh sumber pendanaan baik yang bersifat internal maupun eksternal. Ukuran perusahaan dinyatakan berhubungan positif dan signifikan terhadap nilai perusahaan (Analisa, 2011). Namun ukuran perusahaan mempunyai nilai negatif dan tidak signifikan oleh (Hargiansyah, 2015).

Disamping itu, ada kemungkinan manajemen laba sebagai salah satu cara yang dilakukan manajemen dalam proses penyusunan laporan keuangan yang dapat mempengaruhi tingkat laba yang ditampilkan. 
Hal tersebut diharapkan dapat meningkatkan nilai perusahaan pada saat tertentu. Tujuan earnings management adalah meningkatkan kesejahteraan pihak tertentu walaupun dalam jangka panjang tidak terdapat perbedaan laba kumulatif perusahaan dengan laba yang dapat diidentifikasikan sebagai suatu keuntungan (Fischer dan Rosenzweirg 1995; Scot 1997:294). Earnings management yang dilakukan manajemen perusahaan akan meningkatkan nilai perusahaan (Tobin's Q) lalu kemudian akan turun (Morck, Scheifer \& Vishny 1988).

Berdasarkan penelitan sebelumnya praktek corporate governance memiliki hubungan yang signifikan terhadap earnings management seperti penelitian yang dilakukan Kamil (2014). Sedangkan menurut Melvin dan Herawaty (2010), tidak terdapat hubungan yang signifikan antara praktek corporate governance terhadap earnings management. Konflik keagenan yang mengakibatkan adanya sifat opportunistic manajemen akan mengakibatkan rendahnya kualitas laba. Rendahnya kualitas laba akan dapat membuat kesalahan pembuatan keputusan kepada para pemakainya seperti para investor dan kreditor, sehingga nilai perusahaan akan berkurang.

Komponen dari good corporate governance yang penting untuk ditelusuri adalah dewan komisaris independen, struktur kepemilikan manajerial dan struktur kepemilikan institusional yang merupakan komponen dari mekanisme good corporate governance. Selain itu ada kualitas auditor. Kualitas auditor dapat dilihat dari hasil auditing yang dicerminkan dalam laporan keuangan yang disajikan oleh perusahaan (Indriastuti, 2012). Selain itu menurut Sanjaya (2008) dimensi kualitas auditor yang digunakan dalam penelitian adalah ukuran Kantor Akuntan Publik (KAP) karena nama baik perusahaan KAP dianggap merupakan gambaran yang paling penting.

Beberapa perusahaan KAP menjadi patokan bahwa kualitas audit dalam suatu perusahaan dapat diperhitungkan. Di beberapa penelitian biasanya para peneliti mengukur kualitas audit dengan cara memberi skor. Suatu perusahaan akan diberi skor 1 kualitas auditnya jika laporan keuangan perusahaan diaudit oleh KAP big four. Yaitu, KAP Ernest and Young, KPMG, Delloite dan PWC. Sedangkan untuk yang tidak menggunakan jasa KAP big four diberi skor 0 .

Menurut penelitian yang dilakukan (Arleen Herawaty, 2010) bahwa kualitas audit dan profitabilitas berpengaruh terhadap manajemen laba. Sedangkan good corporate governance dan ukuran perusahaan tidak berpengaruh terhadap manajemen laba. Adapun penelitian - penelitian terdahulu telah membuktikan adanya pengaruh antara Kualitas Audit, Komisaris Independensi Auditor, Mekanisme Good corporate governance dan Leverage terhadap manajemen laba. Studi Azlina (2007) menunjukan bahwa hanya ukuran perusahaan yang berpengaruh secara signifikan terhadap manajemen laba, sedangkan variabel yang lainnya seperti jumlah dewan direksi, leverage dan presentase saham yang ditawarkan kepublik tidak berpengaruh signifikan terhadap manajemen laba. Sementara penelitian yang dilakukan Agusti dan Pramesti (2009) menyatakan bahwa variabel asimetri informasi, ukuran perusahaan dan kepemilikan manajerial berpengaruh signifikan terhadap manajemen laba.

Penelitian Nugrahani (2012) menyatakan bahwa variabel Kualitas Audit tidak memiliki pengaruh signifikan terhadap manajemen laba secara individual, variabel Discretionnary Accruals berpengaruh positif signifikan terhadap nilai perusahaan, dan berdasarkan path analysis yang dilakukan dapat disimpulkan bahwa manajemen laba tidak dapat berperan sebagai variabel intervening pada pengaruh kualitas audit terhadap nilai perusahaan. Beberapa penelitian diatas merupakan penelitian pada perusahaan - perusahaan yang listing pada BEI.

\section{METODE PENELITIAN}

Metode pengumpulan data yang digunakan dalam penelitian ini adalah menggunakan teknik penelitian data sekunder, yaitu menggunakan data dari hasil studi kepustakaan (Library Research) yang berasal dari data laporan keuangan yang dipublikasikan melalui Burse Efek Indonesia.

Analisis data dalam penelitian ini menggunakan analisis kuantitatif yaitu analisis yang bersifat objektif dengan berdasarkan angka-angka dari laporan keuangan kemudian diuji menggunakan uji asumsi klasik lalu diuji kembali menggunakan metode path analysys. 
Printed ISSN 2406-7415

e-ISSN 2655-9919

Jurnal Akuntansi \& Bisnis Krisnadwipayana

Vol. 6 No. 2 (Mei - Agustus) 2019

\section{Path Analysis}

Manfaat dari path analisis adalah untuk penjelasan terhadap fenomena yang dipelajari atau permasalahan yang diteliti, prediksi dengan path analysis ini bersifat kualitatif, faktor determinan yaitu penentuan variabel bebas mana yang berpengaruh dominan terhadap variabel terikat, serta dapat menelusuri mekanisme pengaruh variabel bebas terhadap variabel terikat dengan melibatkan variabel intervening. Analisis jalur merupakan perluasan dari analisis regresi linear berganda, atau analisis jalur digunakan untuk menganalisis pola hubungan antar variabel dengan tujuan untuk mengetahui pengaruh langsung maupun tidak langsung seperangkat variabel bebas (eksogen) terhadap variabel terikat (endogen).pada dasarnya koefisien jalur adalah koefisien regresi yang distandarkan (standardized coefficient regresi). Berikut adalah perumusan substruktur path analisis pada penelitian ini.

Substruktur 1 :

$$
Z=P Z X_{1}+P Z X_{2}+P Z X_{3}+\epsilon_{1}
$$

\section{Substruktur 2 :}

$$
\mathrm{Y}=\mathrm{PY} \mathrm{X}_{1}+\mathrm{PY} \mathrm{X}_{2}+\mathrm{PY} \mathrm{X}_{3}+\epsilon_{2}
$$

\section{Kerangka Pemikiran Teoritis Gambar - 2 \\ Kerangka Penelitian}

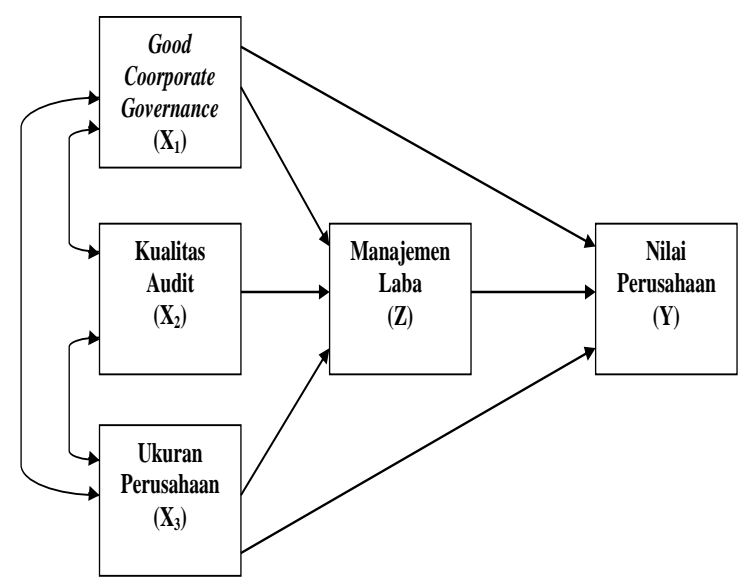

Dari Kerangka konseptual di atas dapat diketahui bahwa ada berbagai keterkaitan antar variabel yang berpengaruh terhadap koefisien respons laba, maka dapat dikemukakan hipotesis penelitian ini adalah sebagai berikut:
$\mathbf{H}_{1} \quad$ : Good corporate governance manajemen laba.

$\mathbf{H}_{2}$ : Kualitas audit berpengaruh signifikan terhadap manajemen laba.

$\mathbf{H}_{3}$ : Ukuran perusahaan berpengaruh signifikan terhadap manajemen laba.

$\mathbf{H}_{4}$ : Good corporate governance, kualitas audit dan ukuran perusahaan berpengaruh signifikan terhadap manajemen laba.

$\mathbf{H}_{5}$ : Good corporate governance berpengaruh signifikan terhadap nilai perusahaan.

$\mathbf{H}_{6}$ : Kualitas audit berpengaruh signifikan terhadap nilai perusahaan.

$\mathbf{H}_{7} \quad$ : $\quad$ Ukuran perusahaan berpengaruh signifikan terhadap nilai perusahaan.

$\mathbf{H}_{8}$ : Good corporate governance, kualitas audit dan ukuran perusahaan berpengaruh signifikan terhadap nilai perusahaan.

$\mathbf{H}_{9}$ : Good corporate governance, kualitas audit, ukuran perusahaan berpengaruh terhadap nilai perusahaan melalui manajemen laba.

\section{HASIL DAN PEMBAHASAN}

Tabel-2

\begin{tabular}{|c|c|c|c|c|c|c|}
\hline \multicolumn{2}{|c|}{ Persamaan } & \multirow{2}{*}{\begin{tabular}{|l|}
\multicolumn{1}{|c}{ Koefisien } \\
Pzx1 $=-0,119$ \\
Pzx2 $=0,040$ \\
Pzx3 $=0,338$ \\
$\epsilon 1 \quad=87,3$ \\
\end{tabular}} & \multirow{2}{*}{\begin{tabular}{|l}
\multicolumn{1}{|c}{$\begin{array}{c}\text { Uji } \\
\text { Signifikans } \\
\text { i Variabel } \\
\text { (t-Statistic })\end{array}$} \\
$G C G=$ \\
0,259 \\
$\mathrm{KA}=0,722$ \\
$\mathrm{UP}=0,003$
\end{tabular}} & \multirow{2}{*}{$\begin{array}{c}\boldsymbol{R}^{2} \\
0,127\end{array}$} & \multirow{2}{*}{$\begin{array}{c}\text { Uji } \\
\text { Model } \\
(\boldsymbol{F} \text { - } \\
\text { statisti } \\
\boldsymbol{c}) \\
0,011\end{array}$} & \multirow{2}{*}{$\begin{array}{r}\text { Adj. } R^{2} \\
0,094\end{array}$} \\
\hline $\begin{array}{c}\text { Tahap } \\
\text { I } \\
\text { (Substruktur } \\
1 \text { ) }\end{array}$ & $\begin{array}{c}\text { Manajemen } \\
\text { Laba }\end{array}$ & & & & & \\
\hline \begin{tabular}{|c|} 
Tahap II \\
(Substruktur \\
2)
\end{tabular} & $\begin{array}{c}\text { Nilai } \\
\text { Perusahaan }\end{array}$ & $\begin{array}{l}\text { Pyx } 1=0,234 \\
\text { Pyz }=0,025 \\
\text { Pyzx3 }=- \\
0,207 \\
\epsilon 2=82,6\end{array}$ & $\begin{array}{l}G C G= \\
0,027 \\
\mathrm{KA}=0,001 \\
\mathrm{UP}=0,077 \\
\mathrm{ML}=0,036\end{array}$ & 0,174 & 0,004 & 0,132 \\
\hline
\end{tabular}

Rekapitulasi Hasil Uji Model

Dalam Tahap 1 (Substruktur 1) terlihat nilai dari Uji F (Uji Model) adalah sebesar 0,011 dapat dikatakan model substruktur 1 dalam penelitian ini berpengaruh dan signifikan (nilai signifikansi $\mathrm{F}<0,05$ maka dapat dikatakan model substruktur 1 tersebut signifikan). Dalam hasil Uji T (Uji Signifikansi Variabel) nilai signifikansi dari variabel 
independen yaitu good corporate governance terhadap variabel dependen (Manajemen Laba) adalah sebesar 0,259 lebih besardari 0,05 (tingkat kesalahan). Hal ini menunjukkan bahwa variabel good corporate governance berpengaruh dan tidak signifikan terhadap Manajemen Laba. Nilai signifikansi dari variabel independen yaitu Kualitas Audit terhadap variabel dependen (Manajemen Laba) adalah sebesar 0,722 lebih besar dari 0,05 (tingkat kesalahan). Hal ini menunjukkan bahwa variabel Kualitas Audit berpengaruh dan tidak signifikan terhadap Manajemen Laba. Nilai signifikansi dari variabel independen yaitu Ukuran Perusahaan terhadap variabel dependen (Manajemen Laba) adalah sebesar 0,003 lebih kecil dari 0,05 (tingkat kesalahan). Hal ini menunjukkan bahwa variabel Ukuran Perusahaan berpengaruh dan signifikan terhadap Manajemen Laba. Nilai Koefisien Determiniasi yang terlihat dari nilai $\mathrm{Adj}, R^{2}$ adalah 0.094 atau sebesar 9,4\%, hal ini menunjukkan bahwa variabel dalam penelitian ini hanya memiliki kontribusi sebesar $9,4 \%$, sedangkan $90,6 \%$ dipengaruhi oleh variabel variabel lain yang tidak terdapat dalam penelitian ini.

Dalam Tahap 2 (Substruktur 2) terlihat nilai dari Uji $\mathrm{F}$ (Uji Model) adalah sebesar 0,0004 dapat dikatakan model substruktur 2 dalam penelitian ini berpengaruh dan signifikan (nilai signifikansi $\mathrm{F}<0,05$ maka dapat dikatakan model substruktur 2 tersebut signifikan). Dalam hasil Uji T (Uji Signifikansi Variabel) nilai signifikansi dari variabel independen yaitu good corporate governance terhadap variabel dependen (Nilai perusahaan) adalah sebesar 0,027 lebih kecil dari 0,05 (tingkat kesalahan). Hal ini menunjukkan bahwa variabel good corporate governance berpengaruh signifikan terhadap Nilai Perusahaan. Nilai signifikansi dari variabel independen yaitu Kualitas Audit terhadap variabel dependen (Nilai Perusahaan) adalah sebesar 0,001 lebih kecil dari 0,05 (tingkat kesalahan). Hal ini menunjukkan bahwa variabel Kualitas Audit berpengaruh terhadap Nilai Perusahaan. Nilai signifikansi dari variabel independen yaitu Ukuran Perusahaan terhadap variabel dependen (Nilai Perusahaan) adalah sebesar 0,077 lebih besar dari 0,05 (tingkat kesalahan). Hal ini menunjukkan bahwa variabel Ukuran Perusahaan berpengaruh dan tidak signifikan terhadap Nilai Perusahaan. Nilai signifikansi dari variabel independen yaitu Manajemen Laba terhadap variabel dependen (Nilai Perusahaan) adalah sebesar 0,036 lebih kecil dari 0,05 (tingkat kesalahan). Hal ini menunjukkan bahwa variabel Manajemen Laba berpengaruh dan signifikan terhadap Nilai Perusahaan. . Nilai Koefisien Determiniasi yang terlihat dari nilai Adj, $R^{2}$ adalah 0,132 atau sebesar $13,2 \%$, hal ini menunjukkan bahwa variabel dalam penelitian ini hanyamemiliki kontribusi sebesar 13,2\%, sedangkan $86,8 \%$ dipengaruhi oleh variabel variabel lain yang tidak terdapat dalam penelitian ini.

Gambar - 3 Kerangka Path Analisis

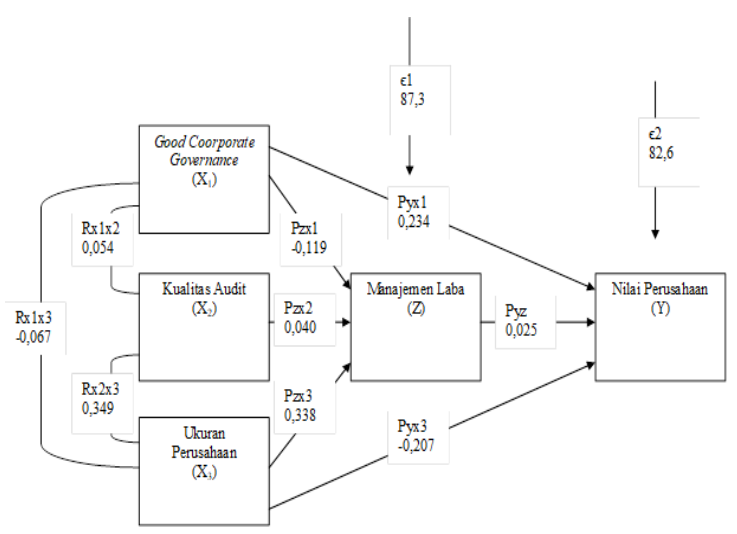

Berdasarkan gambar-3 diatas, maka dapat dibuatkan persamaan struktural untuk model tersebut ialah sebagai berikut :

Substruktur $1: Z=-0,160 X_{1}+0,008 X_{2}+0,054 X_{3}+\epsilon_{1}$ Substruktur $2: Y=0,224 X_{1}-0,043 Z+0,197 X_{3}+\epsilon_{2}$

Dan berdasarkan hasil pengujian menggunakan path analisis diatas dapat diketahui bahwa good corporate governance secara langsung mempunyai pengaruh sebesar -0,119 terhadap manajemen laba, dan tingkat signifikansi menunjukkan bahwa good corporate governance terhadap manajemen laba memperoleh hasil 0,259. Artinya nilai tersebut lebih besar dari tingkat signifikansi 0,005, maka dapat disimpulkan bahwa Ho diterima dan $\mathrm{Ha}$ ditolak, good corporate governance tidak mempunyai pengaruh dan tidak signifikan terhadap manajemen laba. Hasil penelitian ini konsisten dengan penelitian yang dilakukan oleh Welvin I Guna dan Arleen Herawaty 
(2010). Good corporate governance tidak berpengaruh terhadap manajemen laba.

Kualitas Audit secara langsung mempunyai pengaruh sebesar 0,040 terhadap manajemen laba, dan tingkat signifikansi menunjukkan bahwa kualitas audit terhadap manajemen laba memperoleh hasil 0,722. Artinya nilai tersebut lebih besar dari tingkat signifikansi 0,005 , maka dapat disimpulkan bahwa Ho ditolak dan Ha diterima, kualitas audit mempunyai pengaruh namun tidak signifikan terhadap manajemen laba. Hasil penelitian ini konsisten oleh penelitian yang dilakukan oleh Damayanthi (2004) serta Herni dan Susanto (2008). Profitabilitas berpengaruh terhadap manajemen laba.

Ukuran perusahaan secara langsung mempunyai pengaruh sebesar 0,338 terhadap manajemen laba, dan tingkat signifikansi menunjukkan bahwa ukuran perusahaan terhadap manajemen laba memperoleh hasil 0,003 . Artinya nilai tersebut lebih kecil dari tingkat signifikansi 0,005 , maka dapat disimpulkan bahwa Ho ditolak dan Ha diterima, ukuran perusahaan mempunyai pengaruh dan signifikan terhadap manajemen laba. Hasil penelitian ini tidak konsisten oleh penelitian yang dilakukan olehWelvin I Guna dan Arleen Herawaty (2010). Ukuran perusahaan tidak berpengaruh terhadap manajemen laba.

Good corporate governance, kualitas audit dan ukuran perusahaan secara bersama-sama mempunyai pengaruh yang signifikan terhadap manajemen laba, hal tersebut dapat dilihat pada tabel 2. Hasil tersebut menunjukkan bahwa ketiga variabel tersebut memperoleh hasil sebesar 0,011 lebih kecil dari tingkat signifikansi 0,05. Artinya variabel good corporate governance, kualitas audit dan ukuran perusahaan secara bersama-sama mempunyai pengaruh dan signifikan terhadap manajemen laba.

Good corporate governance secara langsung mempunyai pengaruh sebesar 0,234 terhadap nilai perusahaan, dan tingkat signifikansi menunjukkan bahwa good corporate governance terhadap nilai perusahaan memperoleh hasil 0,027 . Artinya nilai tersebut lebih kecil dari tingkat signifikansi 0,005, maka dapat disimpulkan bahwa Ho ditolak dan $\mathrm{Ha}$ diterima, good corporate governance mempunyai pengaruh dan signifikan terhadap nilai perusahaan. Hasil penelitian ini tidak konsisten dengan penelitian yang dilakukan oleh Febriana (2013). Good corporate governance berpengaruh namun tidak signifikan terhadap nilai perusahaan.

Kualitas audit secara langsung melalui tingkat signifikansi menunjukkan bahwa kualitas audit terhadap nilai perusahaan memperoleh hasil 0,001. Artinya nilai tersebut lebih kecil dari tingkat signifikansi 0,005, maka dapat disimpulkan bahwa Ho ditolak dan $\mathrm{Ha}$ diterima, kualitas audit mempunyai pengaruh dan signifikan terhadap nilai perusahaan.

Ukuran perusahaan secara langsung mempunyai pengaruh sebesar $-0,207$ terhadap nilai perusahaan, dan tingkat signifikansi menunjukkan bahwa ukuran perusahaan terhadap nilai perusahaan memperoleh hasil 0,077 . Artinya nilai tersebut lebih besar dari tingkat signifikansi 0,005 , maka dapat disimpulkan bahwa Ho diterima dan Ha ditolak, ukuran perusahaan tidak mempunyai pengaruh dan tidak signifikan terhadap nilai perusahaan. Hasil penelitian ini konsisten dengan penelitian yang dilakukan oleh Yangs Analisa (2011). Ukuran perusahaan tidak berpengaruh terhadap nilai perusahaan.

Good corporate governance, kualitas audit, ukuran perusahaan dan manajemen laba secara bersama-sama mempunyai pengaruh yang signifikan terhadap nilai perusahaan, hal tersebut dapat dilihat pada tabel 3. Hasil tersebut menunjukkan bahwa ke empat variabel tersebut memperoleh hasil sebesar 0,004 lebih kecil dari tingkat signifikansi 0,05. Artinya variabel good corporate governance, kualitas audit, ukuran perusahaan dan manajemen laba secara bersama-sama mempunyai pengaruh dan signifikan terhadap nilai perusahaan.

Berdasarkan kerangka path analisis diatas yang dapat dilihat pada gambar 3, dapat diketahui pula bahwa pengaruh secara total antara variabel good corporate governance terhadap nilai perusahaan melalui manajemen laba sebesar -0,094, artinya variabel good corporate governance mempunyai pengaruh berbanding terbalik terhadap nilai perusahaan melalui manejemen laba.

Pengaruh total antara variabel kualitas audit terhadap nilai perusahaan melalui manajemen laba sebesar 0,065. Artinya kualitas audit mempunyai pengaruh sebesar 0,065 terhadap nilai perusahaan melalui manejemen laba dan pengaruh total antara variabel ukuran 
perusahaan terhadap nilai perusahaan melalui manajemen laba diperoleh sebesar 0,363. Artinya ukuran perusahaan mempunyai pengaruh sebesar 0,363 terhadap nilai perusahaan melalui manejemen laba.

\section{Pembahasan}

Tujuan dari penelitian ini adalah untuk mengetahui mekanismegood corporate governance, kualitas audit, ukuran perusahaan dan implikasinya terhadap nilai perusahaan dengan manajemen laba sebagai variabel intervening padaPerusahaan manufaktur sektor industri barang dan konsumsi yang terdaftar di BEI periode $2011-2015$.

1. Good corporate governance tidak berpengaruh dan tidak signifikan terhadap manajemen laba.

Berdasarkan hasil penelitian menunjukan bahwa good corporate governance tidak berpengaruh dan tidak signifikan terhadap manajemen laba. Hasil penelitian ini mendukung penelitian dari (Melvin I Guna dan Arleen Herawaty,2010) bahwa corporate governance tidak terbukti berpengaruh secara signifikan terhadap manajemen laba. Hal ini menunjukkan bahwa pernanan good corporate governancedengan proksi kepemilikan manajerial, kepemilikan institusi dan dewan komisaris independendalam suatu perusahaan tidak bisa mendeteksi praktek manajemen laba. Kegagalan pihak manajemen yang juga merupakan pemilik modal perusahaan dalam meningkatkan kualitas dan proses pelaporan keuangan disebabkan karena presentase manajer yang memiliki saham relatif sangat kecil jika dibandingkan dengan keseluruhan modal yang dimiliki investor umum.Kepemilikan institusional juga tidak bisa membatasi terjadinya manajemen laba. Hal ini dikarenakan investor institusional tidak berperan sebagai sophisticated investors yang memiliki lebih banyak kemampuan dan kesempatan untuk memonitor dan mendisiplinkan manajer agar lebih terfokus pada nilai perusahaan, serta membatasi kebijakan manajemen dalam melakukan manipulasi laba, melainkan berperan sebagai pemilik sementara yang lebih terfokus pada current earnings

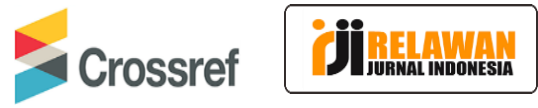

(Yang et al., 2009). Menurut Effendi (2009:20), dalam kaitannya dengan implementasi GCG di perusahaan, diharapkan bahwa keberadaan komisaris termasuk komisaris independen tidak hanya sebagai pelengkap, karena dalam diri komisaris melekat tanggung jawab secara hukum. Namun dalam praktik yang selama ini terjadi di Indonesia, terdapat kecenderungan bahwa kedudukan direksi biasanya sangat kuat, bahkan ada direksi yang enggan membagi wewenang serta tidak memberikan informasi yang memadai kepada komisaris independen. Selain itu, terdapat kendala yang cukup menghambat kinerja komisaris independen yaitu masih lemahnya kompetensi dan integritas mereka. Hal ini terjadi karena pengangkatan komisaris biasanya harus didasarkan pada penghargaan, hubungan keluarga, atau hubungan dekat lainnya, padahal integritas dan independensi merupakan hal yang fundamental agar GCG dalam perusahaan dapat terwujud secara efektif. Oleh karena itulah dewan komisaris independen di perusahaan masih belum bisa bekerja secara efektif dalam meningkatkan pengawasan terhadap operasional perusahaan dan terbukti tidak berpengaruh serta tidak bisa meminimalisir praktik manajemen laba.

2. Kualitas Audit tidak berpengaruh signifikan terhadap manajemen laba

Berdasarkan hasil penelitian menunjukan bahwa kualitas audit tidak berpengaruh signifikan terhadap manajemen laba. Hasil ini konsisten dengan penelitian (Nugrahani, 2012) bahwa kualitas audit tidak berpengaruh signifikan terhadap manajemen laba. Hal inididuga terjadi karena audit atas laporan keuangan yang dilakukan oleh KAP berkualitas yang independen bukanlah ditujukan untuk mendeteksiadanya praktik manajemen laba, melainkan untuk meningkatkankredibilitas laporan keuangan selain itu para pengguna laporan keuanganterutama investor dan calon investor dianggap kurang menyadaripentingnya kualitas auditor dalam melaksanakan proses audit. 
3. Ukuran Perusahaan berpengaruh signifikan terhadap manajemen laba

Berdasarkan hasil penelitian menunjukan bahwa ukuran perusahaan berpengaruh signifikan terhadap manajemen laba. Hasil ini tidak konsisten dengan penelitian (Herawaty, 2010) yang menyatakan bahwa ukuran perusahaan tidak berpengaruh terhadap manejemen laba. Namun penelitian ini konsisten dengan penelitian (Sutikno, 2014) yang menunjukkan bahwa ukuran perusahaan berpengaruh signifikan terhadap manajemen laba. Perusahaan yangberukuran besar lebih diminati oleh para analis dan broker. Apabila perusahaan berukuran besar, maka laporan keuangan yang dipublikasikan lebih bersifat transparan, sehingga memperkecil timbulnya asimetri informasiyang dapat mendukung timbulnya manajemen laba.

4. Good corporate governance berpengaruh signifikan terhadap nilai perusahaan

Berdasarkan hasil penelitian menunjukan bahwa good corporate governance berpengaruh signifikan terhadap nilai perusahaan. Hasil penelitian ini konsisten dengan (Vinola Herawaty, 2008). Bahwa good corporate governance berpengaruh signifikan terhadap nilai perusahaan. Hal ini menunjukkan bahwa implementasi good corporate governanceakan mendorong manajemenuntuk meningkatkan Kinerja dan Nilai Perusahaan yang lebih baik. Hal inidisebabkan karena good corporate governance merupakan seperangkatperaturan yang mengatur hubungan antara pemegang saham, manajer,kreditur, pemerintah, karyawan, dan stakeholders lainnya agar seimbanghak dan kewajibannya (publikasi FCGI). Good Corporate Governancebertujuan untuk mengatur perusahaan agar dapat menciptakan nilai tambahbagi semua stakeholders-nya.

5. Kualitas audit berpengaruh signifikan terhadap nilai perusahaan

Berdasarkan hasil penelitian menunjukan bahwa kualitas audit berpengaruh signifikan terhadap nilai perusahaan. Hasil penelitian ini tidak konsisten dengan penelitian (Nugrahani, 2012), yang menyatakan bahwa kualitas audit tidak berpengaruh signifikan terhadap nilai perusahaan. Namun penelitian ini konsisten dengan penelitian yang dilakukan oleh (Herawaty, 2008), yang menyatakan bahwa kualitas audit yang menggunakan proksi ukuran KAP memiliki pengaruh yang signifikan terhadap nilai perusahaan. Hal ini menunjukkan bahwa kualitas KAP dapat menjadi tolak ukur untuk investor melihat nilai perusahan. karena diasumsikanKAP Big Four dianggap lebih berkualitas karena para auditornya dibekali oleh serangkaian pelatihan dan prosedur serta memiliki program audit yang dianggap lebih akurat dan efektif dibandingkan dengan auditor dari KAP non-Big Four (Isnanta, 2008).

6. Ukuran perusahaan tidak berpengaruh signifikan terhadap nilai perusahaan

Berdasarkan hasil penelitian menunjukan bahwa ukuran perusahaan tidak berpengaruh signifikan terhadap nilai perusahaan. Hal ini sejalan atau konsisten dengan penelitian yang dilakukan oleh (Rifqi Faisal Hargiansyah, 2015), bahwa ukuran perusahaan tidak berpengaruh terhadap nilai perusahaan. Padadasarnya ukuran perusahaan menunjukkan total aset perusahaan, jika nilai ukuranperusahaan tinggi maka semakin besar aktiva yang bisa dijadikan jaminanperusahaan untuk memperoleh hutang maka ada modal perusahaan untukmeningkatkan kinerja dan laba perusahaan yang otomatis meningkatkan nilaiperusahaan. Namun pada penelitian ini dikatakan bahwa ukuran perusahaan tidakbegitu berpengaruh terhadap nilai perusahaan dilihat dari hasil penelitiannya yangtidak signifikan. Hal ini dikarenakan investor membeli saham sebuah perusahaantidak hanya ditinjau dari seberapa besar aktiva perusahaan namun juga dari sisilaporan keuangan, nama baik dan juga kebijakan dividen.

7. Manajemen Laba berpengaruh signifikan terhadap nilai perusahaan

Berdasarkan hasil penelitian menunjukan bahwa manajemen laba berpengaruh signifikan terhadap nilai perusahaan. Hasil penelitian ini bertolak belakang dengan penelitian (Fauzan Kamil, 2014) yang menunjukkan bahwa manajemen laba tidak berpengaruh signifikan terhadap nilai perusahaan. 
Penelitian ini signifikan dengan penelitian (Cahaya Nugrahani, 2012), bahwa manejemen laba berpengaruh positif signifikan terhadap nilai perusahaan. Manajemen Laba merupakan suatu tindakan mengatur laba sesuai yang dikehendaki pihak tertentu, atau terutama oleh manajemen perusahaan (Fahmi, 2012). Pengaturan laba ini bertujuan untuk memperlihatkan kepada pemegang saham bahwa kinerja perusahaan yang terus membaik, yang nantinya akan berpengaruh kepada harga saham, dan nilai perusahaan itu sendiri. Dan hal tersebut menunjukkan bahwa perusahaan yang melakukan manajemen laba makaakan dapat membuat nilai perusahaan menjadi lebih baik.

8. Good corporate governance terhadap nilai perusahaan melalui manajemen laba

Berdasarkan hasil penelitian, diketahui bahwa pengaruh secara langsung antara variabel good corporate governance terhadap nilai perusahaan lebih besar dibandingkan dengan pengaruh tidak langsung antara good corporate governance terhadap nilai perusahaan melalui manejemen laba. Artinya manajemen laba tidak dapat berperan sebagai variabel intervening pada pengaruh good corporate governance terhadap nilai perusahaan.

9. Kualitas audit terhadap nilai perusahaan melalui manajemen laba

Berdasarkan hasil penelitian, diketahui bahwa pengaruh secara langsung antara variabel kualitas auditterhadap nilai perusahaan lebih besar dibandingkan dengan pengaruh tidak langsung antara kualitas auditterhadap nilai perusahaan melalui manejemen laba. Artinya manajemen laba tidak dapat berperan sebagai variabel intervening pada pengaruh kualitas audit terhadap nilai perusahaan.

10. Ukuran Perusahaan terhadap nilai perusahaan melalui manajemen laba

Berdasarkan hasil penelitian, diketahui bahwa pengaruh secara langsung antara variabel ukuran perusahaanterhadap nilai perusahaan lebih kecil dibandingkan dengan pengaruh tidak langsung antara ukuran perusahaan terhadap nilai perusahaan melalui manejemen laba. Artinya manajemen laba disini dapat berperan sebagai variabel intervening pada pengaruh ukuran perusahaan terhadap nilai perusahaan.

\section{KESIMPULAN DAN SARAN \\ Kesimpulan}

Berdasarkan hasil penelitian yang dilakukan diatas yaitu mengenai mekanisme good corporate governance, kualitas audit, ukuran perusahaan terhadap nilai perusahaan melalui manajemen laba sebagai variabel intervening, maka dapat ditarik kesimpulan pada penelitian ini yaitu Good corporate governance tidak berpengaruh secara signifikan terhadap manajemen laba, Kualitas audit mempunyai pengaruh namun tidak signifikan terhadap manajemen laba, Ukuran perusahaan mempunyai pengaruh dan signifikan terhadap manajemen laba, Good corporate governance, kualitas audit dan ukuran perusahaan secara bersama-sama mempunyai pengaruh dan signifikan terhadap manajemen laba, Good corporate governance mempunyai pengaruh dan signifikan terhadap nilai perusahaan, Kualitas audit mempunyai pengaruh dan signifikan terhadap nilai perusahaan, Ukuran perusahaan tidak berpengaruh secara signifikan terhadap nilai perusahaan, Good corporate governance, kualitas audit, ukuran perusahaan dan manajemen laba secara bersama-sama mempunyai pengaruh dan signifikan terhadap nilai perusahaan dan, Pengaruh total malalui manajemen laba terhadap nilai perusahaan lebih besar daripada pengaruh langsung ke nilai perusahaan, artinya manajemen laba dapat berperan sebagai variabel intervening pada pengaruh good corporate governance, kualitas audit dan ukuran perusahaan secara bersama sama terhadap nilai perusahaan.

\section{Saran}

Saran yang diharapkan dapat menjadi bahan pertimbangan bagi peneliti selanjutnya yaitu : Bagi Investor apabila investor ingin berinvestasi dalam suatu perusahaan, maka disarankan untuk memilih perusahaan yang memiliki sistem tata kelola dan nilai perusahaan yang tinggi. Penelitian ini menunjukkan bahwa good corporate governance dan kualitas audit mampu meningkatkan nilai perusahaan. Secara teori juga menunjukkan apabila good corporate governance semakin tinggi, maka kinerja perusahaan akan meningkat, dan akan 
berpengaruh terhadap nilai perusahaan, untuk perusahaan lebih diharapkan untuk memperhatikan penerapan mekanisme corporate governance, sesuai dengan hasil penelitian yang menunjukkan bahwa mekanisme corporate governance berpengaruh signifikan terhadap nilai perusahaan. Dengan diterapkannya mekanisme corporate governance yang baik, maka aspek perusahaan kedepan akan semakin lebih baik lagi dan akan meningkatkan nilai perusahaan.

\section{DAFTAR PUSTAKA}

Agusti, Restu, dan Tyas Pramesti, 2009, Pengaruh Asimetri Informasi, Ukuran Perusahaan, Kepemilikan Manajerial Terhadap Manajemen Laba, Jurnal Ekonomi, Vol. 17, No. 1, 2009 : 0853-7593.

Azlina, Nur, 2007, Analisa Faktor Yang Mempengaruhi Manajemen Laba, Pekbis Jurnal, Vol. 2 No. 3, November, 2010, hal: 355-363.

Cahaya Nugrahani, 2012, Pengaruh Kualitas Audit terhadap Nilai Perusahaan (Manajemen Laba sebagai Variabel Intervening)

Fauzan Kamil, 2014, Pengaruh Manajemen Laba Terhadap Nilai Perusahaan Dengan Mekanisme Corporate Governance Sebagai Variabel Pemoderasi

Febriana, 2013,Pengaruh Good Corporate Governance. Kebijakan Dividen, Manajemen Laba, Dan Kinerja Terhadap Nilai Perusahaan Pada Industri Perbankan Yang Terdaftar Di Bursa Efek Indonesia (Bei) Periode 2010-2012

Haruman, Tendi, (2008), Pengaruh Keputusan Keuangan dan Kepemilikan Institusional Terhadap Nilai Perusahaan. PPM National Conference on Management Research "Manajemen di Era Globalisasi". Hal 1-20. Bandung.

Herawaty, Vinola, 2008, Peran Praktek Corporate Governance Sebagai Moderating Variabel dari Pengaruh Earning Management 121 Terhadap Nilai Perusahaan, Jurnal Akuntansi dan Keuangan, Vol. 10 No. 2, November, 2008, hal: 97-108.
Indriastuti, Maya, 2012, Analisis Kualitas Auditor Dan Corporate Governance Terhadap Manajemen Laba, Eksistansi (ISSN 2085-2401), Vol. IV, No. 2

Isnanta, Rudi, 2008, Pengaruh Corporate Governance Dan Struktur Kepemilikan Terhadap Manajemen Laba Dan Kinerja Keuangan, Skripsi Tidak Dipublikasikan, Fakultas Ekonomi, Universitas Islam Indonesia, Yogyakarta.

Melvin I Guna dan Arleen Herawaty,2010, Pengaruh Mekanisme Good Corporate Governance, Independensi Auditor, Kualitas Audit Dan Faktor Lainnya Terhadap Manajemen Laba

Rifqi Faisal Hargiansyah (2015), Pengaruh Ukuran Perusahaan, Leverage dan Profitabilitas terhadap Nilai Perusahaan (Studi Empiris pada Perusahaan Manufaktur yang Terdaftar di Bursa Efek Indonesia)

Scott, William R, 2009. Financial Accounting Theory. Fifth Edition. Canada Prentice Hall.

Siregar, Sylvia Veronica N.P dan Bachtiar Yanivi S, 2004, Hubungan Antara Manajemen Laba dengan Tingkat Pengungkapan Laporan Keuangan, Simposium Nasional Akuntansi VI. Surabaya.

Sulistyanto, Sri, 2008, Manajemen Laba: Teori dan Model Empiris, Penerbit PT Gramedia Widiasarana Indonesia, Jakarta.

Yangs Analisa, 2011, Pengaruh Ukuran Perusahaan, Leverage, Profitabilitas dan Kebijakan Deviden Terhadap Nilai Perusahaan 
Printed ISSN 2406-7415

e-ISSN 2655-9919

Jurnal Akuntansi \& Bisnis Krisnadwipayana

Vol. 6 No. 2 (Mei - Agustus) 2019

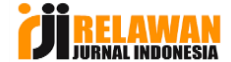

